\title{
RONTGEN TORAKS SEBAGAI PREDIKTOR HASIL TES REVERSE TRANSCRIPTION- POLYMERASE CHAIN REACTION (RT-PCR) UNTUK DIAGNOSIS COVID-19
}

\author{
Rachmi Fauziah Rahayu* , Luths Maharina ${ }^{\star 凶}$, Adam Prabata** Ropitasari ${ }^{\star \star *}$, \\ Widiastuti ${ }^{\star}$, Yuyun Yueniwati ${ }^{\star \star \star *}$
}

\begin{abstract}
Abstrak
COVID-19 merupakan penyakit infeksi yang telah menjangkiti banyak negara di seluruh dunia, termasuk Indonesia. Pemeriksaan RT-PCR merupakan metode standar penegakkan diagnosis COVID-19, namun kapasitas laboratorium di Indonesia belum mampu melakukan pemeriksaan tersebut dalam jumlah adekuat. Rontgen toraks merupakan salah satu modalitas radiologi, yang umum ditemukan dan harganya terjangkau, yang dapat digunakan untuk penapisan pasien suspek COVID-19 sebelum dilakukan pemeriksaan RT-PCR. Rontgen toraks dapat menjadi pilihan modalitas untuk membantu penegakan diagnosis COVID-19 lebih cepat, terutama di daerah dengan fasilitas pemeriksaan RT-PCR yang terbatas. RSUD Dr. Moewardi sebagai salah satu pusat rujukan Posko Kesehatan Siaga COVID-19 di Jawa Tengah melakukan pemeriksaan rontgen toraks sebagai program penapisan dan evaluasi keadaan pasien yang terindikasi terpapar COVID-19. Sejak 4 Mei 2020 hingga 28 Juni 2020, pemeriksaan rontgen toraks sebagai pemeriksaan awal yang dilakukan terhadap 109 subjek dengan lokasi di Instalasi Radiologi RSUD Dr. Moewardi, pemeriksaan kemudian dilanjutkan dengan pemeriksaan RTPCR. Temuan abnormal pada rontgen toraks didapatkan pada $28(25,7 \%)$ orang dengan adanya infiltrat mendominasi pada $17(60,7 \%)$ orang, diikuti dengan gambaran air bronchogram pada $7(25 \%)$ orang, dan GGO pada $4(14,3 \%)$. Temuan abnormal yang ditemukan pada pemeriksaan rontgen toraks pada orang-orang yang bergejala dapat digunakan sebagai prediktor hasil tes RT-PCR untuk diagnosis COVID-19.
\end{abstract}

Kata kunci: COVID-19, penapisan, rontgen toraks.

\section{THE CHEST X-RAY AS A PREDICTOR OF REVERSE TRANSCRIPTION-POLYMERASE CHAIN REACTION (RT-PCR) TEST RESULTS FOR THE DIAGNOSIS OF COVID-19}

\begin{abstract}
COVID-19 is an infectious disease that has infected many countries around the world, including Indonesia. RT-PCR test is the standard method of diagnosing COVID-19, but the capacity of laboratories in Indonesia has not been able to carry out these tests in adequate numbers. Chest X-rays are one of the radiological modalities, which are commonly found and affordable, which can be used to screen patients with suspected COVID-19 before RT-PCR test. Chest X-rays can be a modality of choice to help diagnose COVID-19 more quickly, especially in areas with limited RT-PCR test facilities. Dr. Moewardi Hospital, as one of the referral centers for the COVID-19 Alert Health Post in Central Java, conducts chest X-rays as a screening program and evaluates the condition of patients who are indicated to have been exposed to COVID-19. From 4 May 2020 to 28 June 2020, a chest X-ray examination as an initial examination was carried out on 109 subjects at the Radiology Installation of Dr. Moewardi, the examination was then followed by the RT-PCR test. Abnormal findings on chest X-rays were found in 28 (25.7\%) people with infiltrates predominating in 17 (60.7\%) people, followed by bronchogram in $7(25 \%)$ people, and ground-glass opacity in 4 (14.3). \%). Abnormal findings found on chest X-rays in symptomatic persons can be used as a predictor of RT-PCR test results for the diagnosis of COVID-19.

Keywords: COVID-19, screening, thorax x-ray.

* Departemen Radiologi Fakultas Kedokteran Universitas Sebelas Maret-RSUD dr. Moewardi Surakarta

** Departemen Penyakit Dalam, Divisi Kardiovaskuler, Graduate School of Medicine, Universitas Kobe, Jepang

${ }^{* * *}$ Program Studi D3 Kebidanan, Universitas Sebelas Maret

**** Departemen Radiologi,Fakultas Kedokteran, Universitas Brawijaya-RSUD dr. Syaiful Anwar Malang

घ-mail: luths1082@gmail.com
\end{abstract}




\section{Pendahuluan}

Corona virus disease 2019 (COVID-19) merupakan penyakit yang disebabkan oleh corona virus jenis baru bernama severe acute respiratory syndrome coronavirus 2 (SARS-CoV -2) yang pertama kali dilaporkan muncul di Wuhan, China. ${ }^{1}$ Pada tanggal 10 Agustus 2020, COVID-19 telah menginfeksi hampir 19 juta orang di seluruh dunia, dengan lebih dari 700.000 angka kematian. Kasus COVID-19 di Indonesia per tanggal 10 Agustus 2020 telah melebihi angka 120.000 orang dengan angka kematian lebih dari 5.000 kasus. $^{2}$

Paru-paru merupakan lokasi infeksi primer SARS-CoV-2. Virus tersebut dapat menyerang paru-paru karena paru-paru merupakan salah satu organ yang memiliki angiotensin converting enzyme 2 (ACE2) dalam jumlah banyak dan SARS-CoV-2 membutuhkan ACE2 sebagai reseptor untuk menginfeksi sel. ${ }^{3}$ Melalui serangan terhadap paru-paru, SARS-CoV-2 dapat menyebabkan gejala dengan spektrum yang lebar mulai dari gejala flu ringan hingga pneumonia berat yang mengancam nyawa. ${ }^{4}$

Diagnosis COVID-19 ditegakkan dengan pemeriksaan real time reverse transcriptionpolymerase chain reaction (RT-PCR) menggunakan sampel yang berasal dari swab. Pada pemeriksaan RT-PCR, COVID-19 ditegakkan apabila ribonucleic acid (RNA) SARSCoV-2 terdeteksi dalam kadar tertentu. ${ }^{5}$ Meskipun RT-PCR merupakan metode baku emas untuk diagnosis COVID-19, namun pemeriksaan ini membutuhkan biaya mahal, hanya bisa dilakukan di laboratorium tertentu, dan sulit dilakukan dalam skala besar. ${ }^{6}$ Oleh karena itu, penapisan yang adekuat untuk efisiensi pemeriksan RT-PCT COVID-19 perlu dilakukan.

Rontgen toraks merupakan pemeriksaan radiologi penunjang yang sering dilakukan pada kasus suspek COVID-19 dengan tujuan untuk penapisan. ${ }^{7}$ Computed tomography scan (CTscan) merupakan modalitas radiologi utama untuk mendukung diagnosis dan follow-up, namun CT-scan jumlahnya masih terbatas di Indonesia, sehingga tidak memungkinkan untuk digunakan dalam rangka penapisan COVID-19 skala besar. ${ }^{8}$ Oleh karena itu, rontgen toraks menjadi modalitas radiologi utama yang memungkinkan untuk dilakukan dalam rangka penapisan pasien COVID-19 skala besar.

Dengan semakin meningkatnya jumlah kasus COVID-19 di Indonesia, khususnya di Jawa Tengah maka perlu adanya pemeriksaan penapisan yang adekuat, dan sebagai instansi pemerintah yang ditunjuk oleh Gubernur Provinsi Jawa Tengah, sebagai salah satu Posko Kesehatan Siaga COVID-19, maka instalasi radiologi RSUD dr. Moewardi Surakarta memfasilitasi pemeriksaan rontgen toraks pada pasien -pasien yang bergejala. Penelitian ini bertujuan untuk memeriksa hasil rontgen toraks pada pasien yang terindikasi terpapar COVID-19 sebagai bentuk penapisan dan prediksi sebelum dilakukan pemeriksaan RT-PCR Melalui kegiatan ini diharapkan pemeriksaan RT-PCR dapat dilakukan lebih terarah dan efisien sekaligus terdapat kontribusi terhadap data penapisan pasien COVID-19 menggunakan rontgen toraks di Indonesia, khususnya di RS. dr. Moewardi Surakarta.

\section{Bahan dan Metode}

Secara umum, Posko Kesehatan Siaga COVID-19 ditujukan bagi masyarakat yang mengalami gejala infeksi saluran napas sebelum dilakukan pemeriksaan RT-PCR sebagai dasar diagnosis COVID-19 dan hal tersebut merupakan salah satu bentuk pengabdian kepada masyarakat yang dilaksanakan di lingkungan RSUD dr Moewardi. Metode penapisan gratis yang dilakukan adalah 
dengan melakukan skrining awal berupa anamnesa dan pemeriksan fisik di posko covid RSUD Dr. Moewardi dilanjutkan dengan pemeriksaan rontgen toraks pada pasien yang menunjukan gejala. Poliklinik penapisan gratis ini telah diselenggarakan sejak 16 Maret 2020 hingga sekarang, sesuai dengan instruksi Gubernur Jawa Tengah terkait pandemi COVID-19 yang telah menyebar di Provinsi Jawa Tengah. Semua pasien dengan gejala demam, batuk, pilek, sesak napas, dan memiliki riwayat bepergian dari daerah zona merah mendaftar dan menjalani pemeriksaan penapisan.

Pada penelitian ini, data pasien yang diambil adalah pasien yang menjalani pemeriksaan penapisan rontgen toraks sejak tanggal 4 Mei 2020 hingga 28 Juni 2020. Total pasien yang dilakukan pemeriksaan rontgen toraks adalah 109 pasien. Pemeriksaan rontgen toraks dilakukan instalasi radiologi RSUD Dr. Moewardi Surakarta. Rontgen toraks dilakukan menggunakan alat X-Ray GE Healthcare dengan Protheus Collimatore. Hasil pembacaan rontgen toraks dilakukan oleh dokter spesialis radiologi senior dan spesialis radiologi konsultan toraks dengan pengalaman kerja lebih dari 10 tahun.

Analisis statistik menggunakan metode Chi-Square. Seluruh analisis statistik dilakukan menggunakan aplikasi SPSS 25.0

\section{Hasil}

Pasien yang dilakukan pemeriksaan rontgen toraks untuk penapisan COVID-19 pada kegiatan ini berjumlah 109 orang. Berdasarkan sosiodemografis, didapatkan data karakteristik usia, jenis kelamin, dan pekerjaan pasien, seperti yang terlampir pada Tabel 1. Rata-rata usia pasien adalah $41,6 \pm 15,4$ tahun. Berdasarkan jenis kelamin, terdapat $51(46,8 \%)$ pasien laki-laki dan $58(53,2 \%)$ pasien perempuan.

Tabel 1. Karakteristik subjek

\begin{tabular}{lcc}
\hline Karakteristik Sosiodemografis & Jumlah (Orang) & Frekuensi (\%) \\
& \multicolumn{2}{c}{$41,6+15,4$} \\
\hline Usia (tahun) & \multicolumn{2}{c}{} \\
Jenis Kelamin & 51 & 46,8 \\
Laki-laki & 58 & 53,2 \\
Perempuan & & \\
\hline Karakteristik Klinis & & \\
\hline Gejala & 55 & 50,5 \\
Demam & 75 & 68,8 \\
Batuk & 37 & 33,9 \\
Pilek & 16 & 14,7 \\
Nyeri tenggorokan & 28 & 25,7 \\
Sesak & 21 & 19,3 \\
Pusing & 1 & 0,9 \\
Nyeri perut & 6 & 5,5 \\
Mual muntah & 1 & 0,9 \\
Nyeri otot & 9 & 8,3 \\
BAB cair & 9 & \\
\hline
\end{tabular}


Lanjutan Tabel 1. Karakteristik subjek

\begin{tabular}{lcc}
\hline \multicolumn{1}{c}{ Karakteristik Sosiodemografis } & Jumlah (Orang) & Frekuensi (\%) \\
\hline Swab PCR & 23 & \\
Positif & 15 & 21,1 \\
Negatif & 71 & 13,8 \\
Tidak dilakukan & & 65,1 \\
\hline Karakteristik Hasil Rontgen Toraks & & \\
Temuan abnormal & 28 & 25,7 \\
\hline Ada & 81 & 74,3 \\
Tidak ada & & \\
Jenis temuan abnormal & 26 & 92,9 \\
Pneumonia & 2 & 7,1 \\
Bronkitis & & \\
\hline Lesi abnormal & 17 & 60,7 \\
\hline Infiltrat & 7 & 25 \\
Air bronchogram & 5 & 17,9 \\
GGO & 3 & 10,7 \\
Efusi Pleura & & \\
\hline Jumlah paru yang terdapat lesi & 18 & 64,3 \\
\hline Unilateral & 10 & 35,7 \\
Bilateral &
\end{tabular}

Tabel 2. Asosiasi temuan rontgen toraks dengan diagnosis COVID-19

\begin{tabular}{|c|c|c|c|c|}
\hline \multirow[b]{2}{*}{ Hasil Rontgen Toraks } & \multicolumn{2}{|c|}{ Hasil PCR } & \multirow[t]{2}{*}{ Nilai $p$} & \multirow[t]{2}{*}{$\mathrm{OR}(95 \% \mathrm{Cl})$} \\
\hline & Positif & Negatif & & \\
\hline Temuan Abnormal & & & & $4,93(1,03-23,63)$ \\
\hline Ada & 19 & 9 & 0,044 & \\
\hline Tidak ada & 3 & 7 & & \\
\hline \multirow{2}{*}{\multicolumn{5}{|c|}{$\begin{array}{l}\text { Jenis Temuan Abnormal } \\
\text { Pneumonia }\end{array}$}} \\
\hline & & & & \\
\hline Ada & 18 & 8 & 0,037 & $4,50(1,04-19,39)$ \\
\hline Tidak ada & 4 & 8 & & \\
\hline Efusi Pleura & & & & $1,50(0,12-18,13)$ \\
\hline Ada & 2 & 1 & 0,621 & \\
\hline Tidak ada & 20 & 15 & & \\
\hline Ground Glass Opacity & & & & $3,33(0,37-33,11)$ \\
\hline Ada & 4 & 1 & 0,286 & \\
\hline Tidak ada & 18 & 15 & & \\
\hline Infiltrat & & & & $1,67(0,45-6,19)$ \\
\hline Ada & 11 & 6 & 0,444 & \\
\hline Tidak ada & 11 & 10 & & \\
\hline Air Bronchogram & & & & $0,96(0,18-5,06)$ \\
\hline Ada & 4 & 3 & 0,641 & \\
\hline Tidak ada & 18 & 13 & & \\
\hline
\end{tabular}


Berdasarkan pemeriksaan rontgen toraks, terdapat $28(25,7 \%)$ pasien yang ditemukan adanya temuan abnormal di paru. Pneumonia mendominasi temuan abnormal dengan ditemukan pada 26 (92,9\%) pasien dan bronkitis hanya ditemukan pada $2(7,1 \%)$ pasien. Infiltrat menjadi lesi yang paling banyak ditemukan pada pasien dengan temuan abnormal di paru yaitu pada $17(60,7 \%)$ pasien, air bronchogram ditemukan pada 7 (25\%) pasien, ground glass opacity (GGO) ditemukan pada $5(17,9 \%)$ pasien, efusi pleura ditemukan pada $3(10,7 \%)$ pasien. Kelainan di paru bisa satu sisi (unilateral) maupun di kedua sisi (bilateral). Berdasarkan kelainan di satu paru atau kedua sisi paru yang terdapat lesi didapatkan $18(64,3 \%)$ pasien memiliki lesi paru unilateral dan 10 $(35,7 \%)$ pasien memiliki lesi paru bilateral.

Berdasarkan karakterisik klinis, gejalagejala yang ditemukan pada pasien yang menjalani pemeriksaan penapisan antara lain demam sejumlah 55 (50,5\%) orang, batuk 75 $(68,8 \%)$ orang, pilek $37(33,9 \%)$ orang, nyeri tenggorokan $16(14,7 \%)$ orang, sesak 28 $(25,7 \%)$ orang, pusing $21(19,3 \%)$ orang, nyeri perut $1(0,9 \%)$ orang, mual muntah $6(5,5 \%)$ orang, nyeri otot $1(0,9 \%)$ orang, dan BAB cair 9 $(8,3 \%)$ orang. Terdapat $38(34,9 \%)$ orang yang menjalani pemeriksaan RT-PCR berdasarkan pemeriksaan penapisan rontgen toraks, dengan $23(21,1 \%)$ orang terbukti positif COVID-19 dan $15(13,8 \%)$ orang terbukti negatif COVID-19.

Berdasarkan Tabel 2, terdapat hubungan bermakna antara temuan abnormal pada rontgen toraks dengan hasil RT-PCR, dengan nilai $p=0,044$, dengan jenis temuan abnormal pneumonia merupakan variabel yang bermakna dengan nilai $p=0,037$. Sementara untuk temuan abnormal lainnya memiliki nilai $p>0,05$. Untuk temuan abnormal efusi pleura nilai $p=$ 0,621 , untuk temuan ground glass opacity nilai $p=0,286$, untuk infiltrat dan air bronchogram masing masing memiliki nilai $p=0,444$ dan 0,641 .

\section{Pembahasan}

Rontgen toraks merupakan pemeriksaan yang memiliki sensitivitas rendah untuk COVID19, terutama bila dibandingkan dengan CTScan. ${ }^{9}$ Perbedaan antara COVID-19 dengan pneumonia yang disebabkan oleh virus lain sulit untuk ditentukan hanya berdasarkan temuan rontgen toraks. ${ }^{8}$ Yoon (2020) menemukan 33\% pasien COVID-19 memiliki temuan abnormal pada pemeriksaan rontgen toraks, sedangkan Durrani (2020) menemukan 93\% pasien COVID -19 memiliki temuan abnormal pada pemeriksaan rontgen toraks. 8,10 Pada penelitian ini ditemukan $25,7 \%$ pasien dengan temuan abnormal pada pemeriksaan rontgen toraks, namun angka tersebut berasal dari keseluruhan pasien yang dilakukan penapisan, bukan spesifik pada pasien yang terinfeksi COVID-19. Penelitian lanjutan dalam bentuk pemeriksaan rontgen toraks khusus pada pasien yang sudah terbukti terinfeksi COVID-19 perlu dilakukan untuk memastikan terdapatnya temuan abnormal berdasarkan pemeriksaan rontgen toraks.

Pada penelitian ini, temuan abnormal pada rontgen toraks dapat menjadi prediktor hasil RTPCR yang positif COVID-19 ( $p=0,044)$. Temuan abnormal yang dimaksud khususnya adalah temuan pneumonia pada rontgen toraks $(p=0,037)$.

Program penapisan melalui pemeriksaan rontgen toraks pada pasien COVID-19 yang bergelaja ini juga sangat penting untuk meningkatkan efisiensi pemeriksaan RT-PCR, mengingat cakupan pemeriksaan RT-PCR COVID-19 di Indonesia masih di bawah standar yang ditetapkan oleh WHO yaitu 1/1000 populasi per minggu. ${ }^{2}$ 
Selain itu, kapasitas pemeriksaan CT-Scan, yang merupakan pilihan utama modalitas radiologi untuk COVID-19 di Indonesia juga masih belum banyak. Melalui program penapisan pasien COVID-19 dengan rontgen toraks ini diharapkan pemeriksaan RT-PCR yang masih terbatas di Indonesia dapat digunakan secara lebih tepat sasaran untuk mendeteksi pasien yang positif COVID-19. Gratisnya program ini membuat cakupan penapisan juga dapat diakses oleh semua lapisan masyarakat.

\section{Kesimpulan}

Pada penelitian ini hasil pemeriksaan rontgen toraks menunjukkan adanya temuan abnormal pneumonia yang dapat dijadikan sebagai prediktor hasil RT-PCR yang positif. Hal ini dapat membantu penegakan diagnosis COVID-19 menjadi lebih cepat dan pasien dapat lebih cepat dilakukan tata laksana.

\section{Saran}

Penelitian lanjutan dengan subjek orang yang terinfeksi COVID-19 dengan konfirmasi hasil RT-PCR diperlukan untuk mengatahui lebih lanjut akurasi pemeriksaan rontgen toraks serta berbagai temuan abnormal yang dapat muncul.

\section{Daftar Pustaka}

1. Guo YR, Cao QD, Hong ZS, et al. The Origin, Transmission and Clinical Therapies on Coronavirus Disease 2019 (COVID-19) Outbreak-an Update on the Status. Mil Med Res. 2020; 7(11):1-10.

2. World Health Organization (WHO). Coronavirus Disease (COVID-19) Situation Report203. (Online). 2020. Available from: https:// www.who.int/docs/default-source/ coronaviruse/situation-reports/20200810covid-19-sitre p- 203 . pd f ? sfvrsn=aa050308_2.

3. Perotta $F$, Matera MG, Cazzola M, et al. Severe Respiratory SARS-CoV2 Infection: Does ACE2 Receptor Matter?. Respir Med. 2020; 168:105996.

4. Zhai $P$, Ding $Y, W u X$, et al. The Epidemiology, Diagnosis and Treatment of COVID-19. International Journal of Antimicrobial Agents. 2020; 55(5):105955.

5. Fang FC, Naccache SN, Greninger AL. The Laboratory Diagnosis of Coronavirus Disease 2019-Frequently Asked Questions. Clinical Infectious Diseases. 2020; 71 (11):2996-3001. doi: 10.1093/cid/ciaa742.

6. Dorlass EG, Monteiro CO, Viana AO, et al. Lower Cost Alternatives for Molecular Diagnosis of COVID-19: Conventional RT-PCR and SYBR Green-Based RT-qPCR. Braz J Microbiol. 2020; 51(3):1117-1123. doi: 10.1007/s42770-020-00347-5.

7. Jacobi $A$, Chung $M$, Bernheim $A$, et al. Portable Chest X-ray in Coronavirus Disease (COVID-19): a Pictorial Review. Clin Imaging. 2020; 64;35-42.

8. Durrani M, Haq I, Kalsoom U, et al. Chest XRays Findings in COVID-19 Patients at a University Teaching Hospital - a Descriptive Study. Pak J Med Sci. 2020; 36(COVID19S4):S22-S26.

9. Zhou Z, Guo D, Li C, et al. Coronavirus Disease 2019: Initial Chest CT Findings. Eur Radiol. 2020; 30:4398-4406.

10. Yoon SH, Lee KH, Kim JY, et al. Chest Radiographic and CT Findings of the 2019 Novel Coronavirus Disease (2019): Analysis of Nine Patients Treated in Korea. Korean J Radiol. 2020; 21(4):498-504. 